JRPB, Vol. 7, No. 1, Maret 2019, Hal. 105-115

DOI: $10.29303 /$ jrpb.v7i1.103

ISSN 2301-8119, e-ISSN 2443-1354

Tersedia online di http://jrpb.unram.ac.id/

\title{
KARAKTERISTIK PENGERINGAN SAWUT MOCAF MENGGUNAKAN ALAT PENGERING TENAGA SURYA TIPE GREENHOUSE
}

\author{
Characteristics of Modified Cassava Flour (MOCAF ) Drying \\ using Greenhouse Type Solar Dryer
}

\section{Murad $^{1, *)}$, Rahmat Sabani ${ }^{1}$, Hary Kurniawan ${ }^{1}$, Surya Abdul Muttalib', Fakhrul Irfan Khalil ${ }^{1}$}

\author{
${ }^{1}$ Program Studi Teknik Pertanian, Fakultas Teknologi Pangan dan Agroindustri, \\ Universitas Mataram \\ Email*): muradfatepa@unram.ac.id
}

\begin{abstract}
The aim of this research is to study the drying characteristics of Modified Cassava Flour (MOCAF) using Greenhouse Type Solar Dryer. The methodology used in this study was experimental method to measure several parameters, reduction in material weight, moisture content, temperatures of dryer, ambient temperature, air humidity, and drying rate. The tools used were Greenhouse Type Solar Dryer, CC (Cooper Constanta) type CA Thermocouples, digital scales, analytical scales, anemometer, data record, lux meter, stop watch, stem thermometer, and stationery. Data was retrieved every 30 minutes. The results showed the temperature profile in drying room at every rack and in the air tunnel through exhaust fan. The increasing solar radiation generally occured at noon around 12.00 until 13.00, though decreasing solar radiation happened when the data retrieved in cloudy sky. The approximate drying room temperature was $39^{\circ} \mathrm{C}$, relative humidity was $63 \%$, decreasing material weight per hour was $0.95 \mathrm{gram} / \mathrm{h}$, the rate of decreased water content was $55.25 \% \mathrm{db} / \mathrm{h}$ from the initial moisture content of $67 \%$ db until moisture content reached $10 \%$ and Equalibrium Moisture Content $(\mathrm{Me})$ value achieved $14.22 \%$. From the research results, it can be concluded that the water content decreasing rate has a characteristic of declining over time.
\end{abstract}

Keywords: drying, Modified Cassava Flour (MOCAF), grenhouse dryer, moisture content, drying rate.

\begin{abstract}
ABSTRAK
Tujuan dari penelitian ini adalah untuk mempelajari karakterisitik Pengeringan Sawut Mocaf menggunakan alat pengering tenaga surya tipe greenhouse. Metodologi yang digunakan dalam penelitian ini adalah metode eksperimental dengan mengukur beberapa parameter, yaitu penurunan berat bahan, kadar air, suhu pengering, suhu lingkungan, kelembaban udara dan laju pengeringan. Alat yang digunakan adalah pengering tenaga surya tipe greenhouse, termokopel CA tipe CC (Cooper Constanta), timbangan digital, timbangan analitis, anemometer, rekam data, luxmeter, stopwatch, termometer batang dan alat tulis. Pengambilan data dilakukan setiap 30 menit. Hasil penelitian menunjukkan karakteristik suhu di dalam ruang pengering ERK yang
\end{abstract}


diukur pada setiap rak dan pada bagian saluran udara keluar melalui exhaust fan. Peningkatan radiasi surya pada umumnya terjadi pada tengah hari yaitu sekitar pukul 12.00 wita sampai pukul 13.00 wita, sedangkan pada saat pemantauan ERK kondisi cuaca cukup berawan sehingga terjadi penurunan radiasi surya. Didapatkan rata-rata temperatur ruang pengering selama pengeringan adalah $39^{\circ} \mathrm{C}$, kelembaban udara relatif rata-rata $63 \%$, penurunan berat bahan tiap jam rata-rata 0,95 gram/jam, laju penurunan kadar air rata-rata 55,25\% db/jam dari kadar air awal sebesar $67 \%$ db sampai kada air mencapai $10 \%$ db dan rata-rata Me diperoleh sebesar 14,22\%. Dari hasil penelitian pengeringan sawut mocaf yang diperoleh, maka disimpulkan bahwa laju perubahan kadar air MOCAF memiliki karakteristik laju menurun terhadap waktu.

Kata kunci: pengeringan, sawut $M O C A F$, greenhouse, kadar air, laju pengeringan

\section{PENDAHULUAN}

Provinsi Nusa Tenggara Barat merupakan salah satu daerah penghasil ubi kayu di Indonesia dengan luas lahan produksi sebesar 4.706 hektar, jumlah produksi sebesar, 92.643 ton, dan produktivitas rata-rata sebesar 196,9 kwintal/hektar. Ubi kayu (Manihot utulisima cassava) merupakan salah satu produk pangan hasil pertanian yang sangat potensial dan prospektif untuk dikembangkan sebagai produk pangan lokal dan dapat didiversifikasi menjadi berbagai macam pangan olahan (BPS, 2016).

Ubi kayu dapat diolah menjadi beraneka ragam produk olahan dan sebagai bahan baku industri seperti tepung tapioka, tepung mocaf, tepung gaplek dan sebagai bahan baku pembuatan bioetanol. Upaya untuk memperluas penggunaan ubi kayu sebagai bahan pangan, dapat dilakukan melalui penanganan pasca panen dan pengolahan dalam bentuk tepung. Dibandingkan dengan ubi kayu segar, ubi kayu dalam bentuk tepung memiliki masa simpan yang lebih panjang dan aplikasi penggunaannya yang lebih luas. Subtitusi terigu dengan tepung ubi (tepung mocaf) pada industri makanan olahan diperkirakan akan mengurangi penggunaan terigu sekitar 1.4 juta ton per tahun dan dapat menghemat penggunaan gula hingga 20\% (Wulandani dan Utari, 2013).

Proses pembuatan dan atau pengolahan tepung singkong umumnya dilakukan dengan metode sawut. Pengolahan tepung singkong menggunakan metode sawut memiliki berbagai kelemahan seperti tingkat elastisitas yang rendah pada adonan. Berbagai kegiatan perbaikan karakteristik tepung singkong telah dilakukan oleh sejumlah peneliti, antara lain dengan metode fermentasi. Pengembangan teknologi pengolahan tepung singkong secara fermentasi dalam bentuk tepung MOCAF (modified cassava flour) (Hidayat, dkk., 2009).

Proses pengolahan singkong menjadi tepung singkong fermentasi (MOCAF) melalui beberapa tahapan, salah satunya adalah melalui proses pengeringan. Proses pengeringan dilakukan untuk mengurangi kadar air yang terkandung pada ubi kayu. Pengurangan kadar air bahan ubi kayu yang dikeringkan akan memepermudah dalam pengolahan dan meningkatkan kualitas dari tepung mocaf . Selain itu, pengeringan akan meningkatkan umur simpan dan memberikan tekstur yang lebih baik.

Proses pengeringan sawut singkong fermentasi sebagai bahan pembuatan mocaf selama ini masih dilakukan dengan cara tradisional yaitu pengeringan secara langsung dengan sinar matahari. Bahan sawut singkong diletakkkan di atas para-para dan atau alas plastik (terpal) yang diletakkan di atas lantai jemur. Jika ditinjau dari segi ekonomis, pengggunaan sinar Ultra Violet sangat ekonomis dan tersedia dalam jumlah tak terbatas, terlebih bagi negara-negara beriklim tropis. Namun kekurangan pengeringan menggunakan sinar matahari sangat tergantung pada cuaca, produk yang 
dihasilkan kurang higienis dan berpotensi untuk terkontaminasi oleh kotoran. Kondisi cuaca yang cenderung fluktuatif dan hujan akan memepengaruhi proses pengeringan menggunakan sinar matahari (Catur, 1991). Oleh karena itu, diperlukan suatu pengering mekanis untuk meningkatkan produktivitas, faktor higienis dan keberlanjutan produksi tepung mocaf .

Penggunaan alat pengering buatan seperti pengering tenaga surya tipe greenhouse atau Efek Rumah Kaca (ERK) merupakan salah satu upaya peningkatan efisiensi pengeringan, mutu dan kualitas produk tepung mocaf yang dihasilkan. Alat pengering tenaga surya tipe greenhouse dengan sistem bangunan tertutup dan bahan transparan tembus sinar matahari serta dapat melindungi produk dari kontaminan dan hujan. Penggunaan pengering tipe greenhouse terbukti mampu meningkatkan suhu pada alat pengering sebesar $40-50^{\circ} \mathrm{C}$ pada suhu lingkungan $27-30^{\circ} \mathrm{C}$. Oleh sebab itu, pengeringan sawut mocaf dengan menggunakan pengering tipe greenhouse dimungkinkan menjadi salah satu alternatif yang tepat dalam proses pembuatan tepung mocaf.

\section{METODOLOGI PENELITIAN}

Bahan dasar yang digunakan pada penelitian ini adalah ubi kayu atau singkong segar varietas hybrida dengan ukuran besar dan berat rata-rata per umbi sebesar 300-400 gram. Bahan penelitian singkong diperoleh dari petani singkong yang ada di kecamatan Labuan Haji kabupaten Lombok Timur. Bahan sawut mocaf yang dikeringkan berukuran rata-rata panjang $4 \mathrm{~cm}$, lebar $2 \mathrm{~cm}$ dan dengan ketebalan $0,2 \mathrm{~cm}$.

Alat yang digunakan adalah 1 unit alat pengering tenaga surya tipe Greenhouse (ERK), termokopel CA tipe CC (Cooper Constanta), timbangan digital, Timbangan Analitis, anemometer, rekam data, luxmeter, stopwatch, termometer batang air raksa dan alat tulis.

Bahan baku singkong tersebut disawut dengan menggunakan mesin penyawut dan difermentasi dengan perendaman menggunakan air selama 3 hari dan selama proses fermentasi air rendaman diganti setiap 24 jam. Pengeringan sawut mocaf ini dilakukan dengan perlakuan tingkat ketebalan lapisan bahan pada masing-masing rak atas, rak tengah dan rak bawah. Kapasitas bahan sawut mocaf yang dikeringkan pada penelitian ini adalah dengan massa masing-masing 10-15 kg tiaptiap rak dan dengan ukuran ketebalan tumpukan bahan sebesar 1-1,5 cm. Pengeringan dibatasi sampai mencapai kadar air keseimbangan yang dapat diketahui dari perbedaan berat sawut mocaf selama pengeringan dalam dua kali pengukuran diperoleh hasil penimbangan dengan berat yang yang berbeda. Adapun beberapa asumsi yang digunakan untuk menyederhanakan dalam menganalisis data, yaitu:

1. Kadar air awal sawut mocaf yang digunakan pada penelitian tahap pertama dan tahap berikutnya adalah berbeda tergantung situasi bahan.

2. Proses pengeringan produk dipengaruhi oleh suhu dan $\mathrm{RH}$ ruang pengering.

3. Membandingkan data pengamatan dengan data simulasi yang dihitung berdasarkan model persamaan Hall dari sebuah proses pengeringan sawut mocaf dengan menggunakan persamaan nilai persentase kesalahan relatif (Roat Mean Square atau ERMS) sebagai berikut:

$\% E R M S=\sqrt{\frac{\sum\left[\frac{M_{o b s}-M_{\text {sim }}}{M \text { sim }}\right]^{2}}{n}} \times 100 \% \ldots . . .(1)$

Dimana: RMS adalah efisiensi model, $M_{o b s}$ adalah nilai observasi atau terukur, $M_{\text {sim }}$ adalah nilai simulasi atau dihitung berdasarkan model, dan $n$ adalah jumlah data.

Variabel yang dihitung adalah penurunan berat bahan, kadar air, perubahan suhu ruang pengering dan suhu pengeringan, suhu lingkungan, suhu udara keluar, suhu bahan, kelembaban udara, dan laju pengeringan. 
Data hasil penelitian ini ditampilkan dalam bentuk tabel dan grafik. Data observasi yang diperoleh dari percobaan di lapangan dibandingkan dengan data prediksi yang diperoleh dari persamaan pendekatan statistik. Persamaan pendekatan statistik dikatakan valid apabila nilai \% ERMS kurang dari $10 \%$. Nilai ERMS dihitung dengan persamaan pada persamaan (1).

\section{HASIL DAN PEMBAHASAN}

\section{Temperatur / Suhu Pengeringan (T)}

Suhu merupakan salah satu faktor yang sangat penting dalam proses pengeringan. Dalam proses pengeringan diperlukan suhu yang relatif tinggi untuk menguapkan air yang ada di dalam bahan. Laju penguapan air bahan dalam pengeringan sangat ditentukan oleh kenaikan suhu. Makin tinggi suhu dan kecepatan aliran udara pengering makin cepat pula proses pengeringan berlangsung. Makin tinggi suhu udara pengering makin besar energi panas yang dibawa udara sehingga makin banyak jumlah massa cairan yang diuapkan dari permukaan bahan yang dikeringkan (Murad, dkk., 2017).

Karaketerisitik suhu di dalam ruang pengering tipe Greenhouse atau Efek Rumah Kaca (ERK) diukur setiap rak dan pada bagian saluran udara keluar melalui exhaust fan. Berdasarkan Grafik pada gambar 1 terlihat bahwa pola sebaran suhu antara rak satu dengan lainnya bervariasi. Variasi suhu antar rak disebabkan oleh intensitas radiasi surya yang diterima berbeda, serta terkait dengan sudut datangnya sinar matahari yang diterima oleh permukaan rak, di mana sinar yang miring kurang memberikan energi panas pada permukaan rak. Peningkatan radiasi surya pada umumnya terjadi pada tengah hari yaitu sekitar pukul 12.00 wita sampai pukul 13.00 wita, sedangkan pada saat pemantauan ERK kondisi cuaca cukup berawan sehingga terjadi penurunan intensitas matahari.

Grafik pada gambar 2, 3 dan 4 menunjukkan hubungan antara waktu pengeringan dengan kenaikan suhu pada ruang pengering. Suhu pada ruang pengering mengalami peningkatan dan penurunan seiring dengan semakin lamanya waktu pengeringan. Sedangkan pada sore hari suhu mulai menurun. Hal ini dipengaruhi oleh sumber energi panas untuk pengeringan diperoleh dari sinar matahari, sehingga kualitas dan lama proses pengeringan sangat tergantung pada intensitas cahaya matahari. Akan tetapi dengan menerapkan metode pengeringan dengan memanfaatkan efek rumah kaca ini mampu mengoptimalkan proses pengeringan sawut mocaf dengan efisiensi yang relatif lebih tinggi

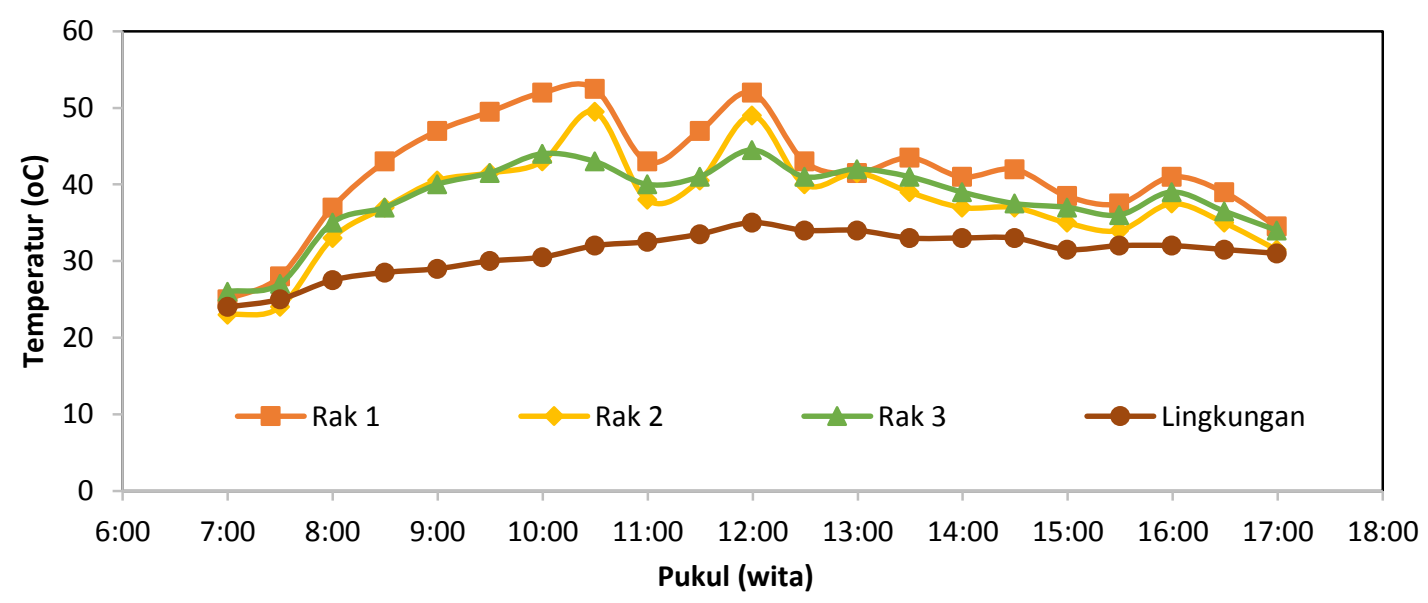

Gambar 1. Grafik suhu tiap rak dengan lingkungan pada kondisi tanpa bahan 


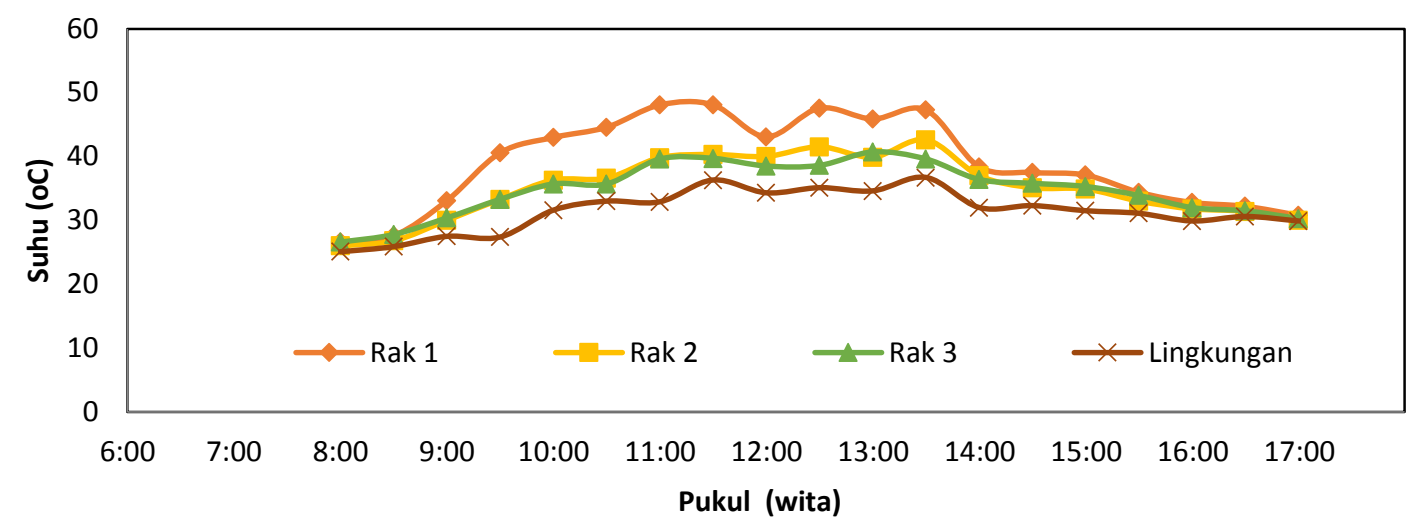

Gambar 2. Grafik kondisi suhu pengeringan sawut mocaf pada hari pertama

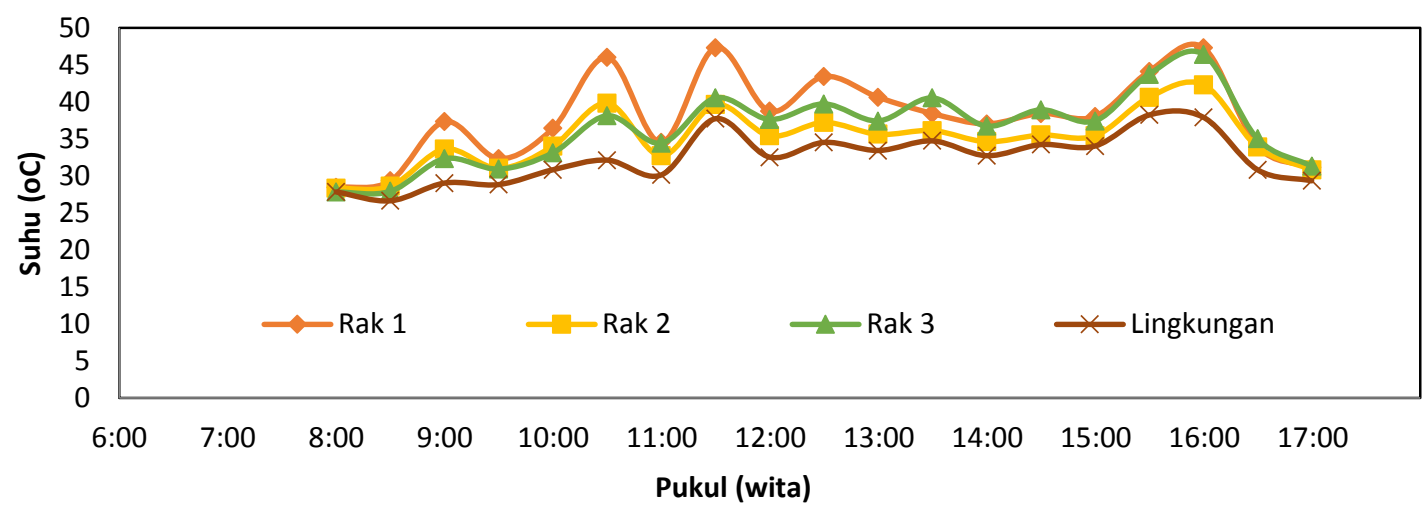

Gambar 3. Grafik kondisi suhu pengeringan sawut mocaf pada hari kedua

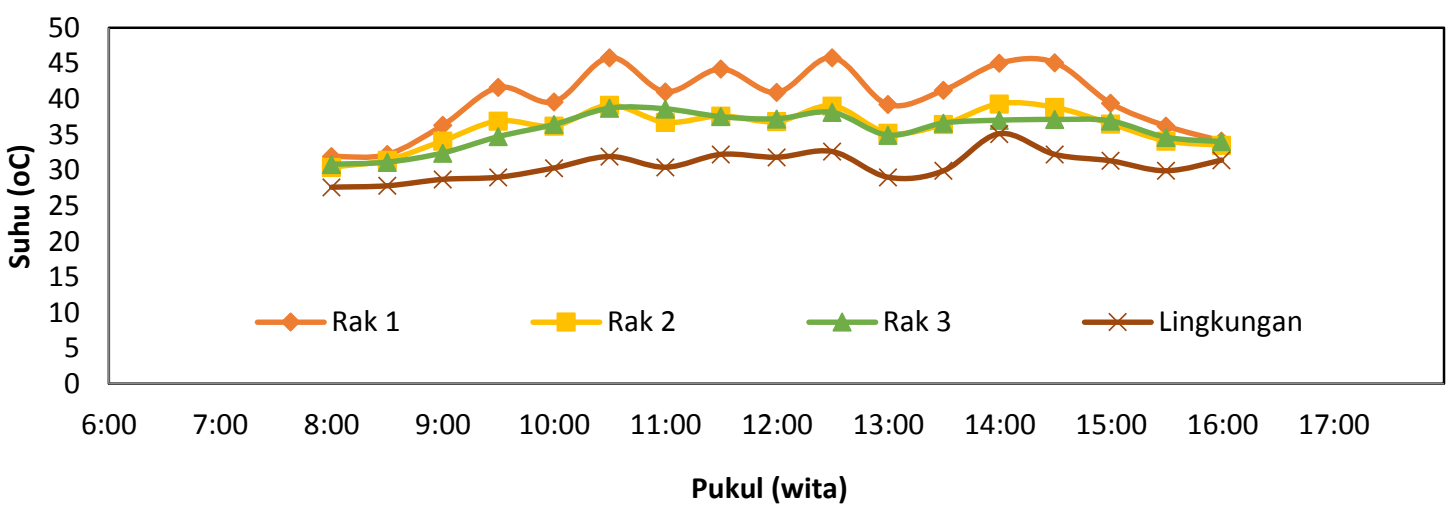

Gambar 4. Grafik kondisi suhu pengeringan sawut mocaf pada hari ke tiga

\section{Kelembaban Relatif (RH)}

Kelembaban relatif udara untuk pengering menunjukkan kemampuan udara untuk menyerap uap air. Udara panas yang ada di dalam ruang pengering secara perlahan akan memanaskan dan menguapkan massa air di dalam mocaf. Dalam proses pengeringan kelembaban relatif menjadi faktor yang mempengaruhi laju pengeringan.
Grafik kondisi kelembaban relatif ditunjukkan pada gambar 5 .

Berdasarkan grafik menunjukkan bahwa terjadi perbedaan kelembanan di setiap rak di dalam greenhouse. Kondisi udara paling kering terdapat di area rak 1 yaitu pada level paling atas di dalam greenhouse, di mana $\mathrm{RH}$ rata-rata yang terukur berturut-turut pada rak 1, rak 2 dan 
rak 3 adalah 59\%, 63\% dan 67\%. Sedangkan $\mathrm{RH}$ rata-rata di lingkungan atau di luar greenhouse adalah $88 \%$. Dengan demikian dapat disimpulkan bahwa kondisi $\mathrm{RH}$ di dalam greenhouse sangat berpotensi untuk proses pengeringan sawut Mocaf .

Perbandingan kondisi suhu dan $\mathrm{RH}$ di dalam greenhouse dengan lingkungan dapat dilihat pada Gambar 5. Dari grafik tersebut dapat dilihat pola pengaruh suhu terhadap RH di dalam greenhouse dan di luar greenhouse. Ketika suhu meningkat, terjadi penurunan $\mathrm{RH}$ dan sebaliknya. Terdapat perbedaan kondisi suhu dan RH di dalam dan di luar greenhouse, di mana suhu di greenhouse relatif lebih tinggi dari pada di luar, dan RH di dalam lebih rendah dari pada RH di luar greenhouse.

Semakin rendah nilai kelembaban relatif udara pengering, maka kemampuannya dalam mengikat uap air akan semakin besar. Hal sebaliknya akan terjadi jika kelembaban relatif udara pengeringan semakin besar, maka kemampuannya dalam menyerap uap air akan semakin kecil. Kelembaban relatif udara pengering menunjukkan kemampuan udara untuk menyerap uap air (Murad, dkk, 2015). Udara panas yang dimiliki ruang pengering secara perlahan akan memanaskan dan menguapkan massa air di dalam sawut singkong. Hal ini sesuai dengan pernyataan Murad, dkk (2015), pada suhu yang tinggi tekanan uap air jenuh akan meningkat sehingga kelembaban relatif sebagai nilai perbandingan antara tekanan parsial uap air di udara dengan tekanan uap jenuh pada suhu yang sama akan semakin rendah. Suhu tertinggi diperoleh pada rak atas dan suhu terndah diperoleh pada rak bawah. Sehingg $\mathrm{RH}$ tertinggi diperoleh pada rak bawah dan $\mathrm{RH}$ terendah pada rak atas. $\mathrm{RH}$ pada ruang pengering juga mengalami fluktuasi seiring dengan perubahan kondisi penyinaran matahari, selain itu juga karena tidak dilakukan rekayasa pada kondisi $\mathrm{RH}$ di dalam ruang pengering sehingga tren $\mathrm{RH}$ khususnya pada malam hari hampir mendekati RH lingkungan yakni di atas 70 $\%$.

Pada malam hari tidak ada sumber energi panas, tetapi hanya memanfaatkan exhaust fan untuk menjaga kondisi kelembaban di dalam green house tetap stabil. Perlakuan ini ternyata memberi manfaat yang cukup baik karena terjadi penguapan uap air dari mocaf yang ditandai dengan penurunan berat.

Berdasarkan Grafik pada Gambar 7, 8 dan 9 dapat dilihat pola sebaran RH tiap rak di dalam green house yang dibandingkan dengan RH lingkungan. Rerata nilai kelembaban paling tinggi adalah pada rak tiga, sedangkan nilai RH terendah adalah pada rak 1 yang paling atas. Kondisi rak 1 yang memiliki nilai RH paling rendah karena terpapar langsung dengan sinar matahari tanpa ada naungan dari sisi manapun. Sedangkan pada rak 2 dan rak 3 terjadi naungan mulai dari sekitar pukul 12.00 wita sampai dengan sekitar pukul 13.00 wita

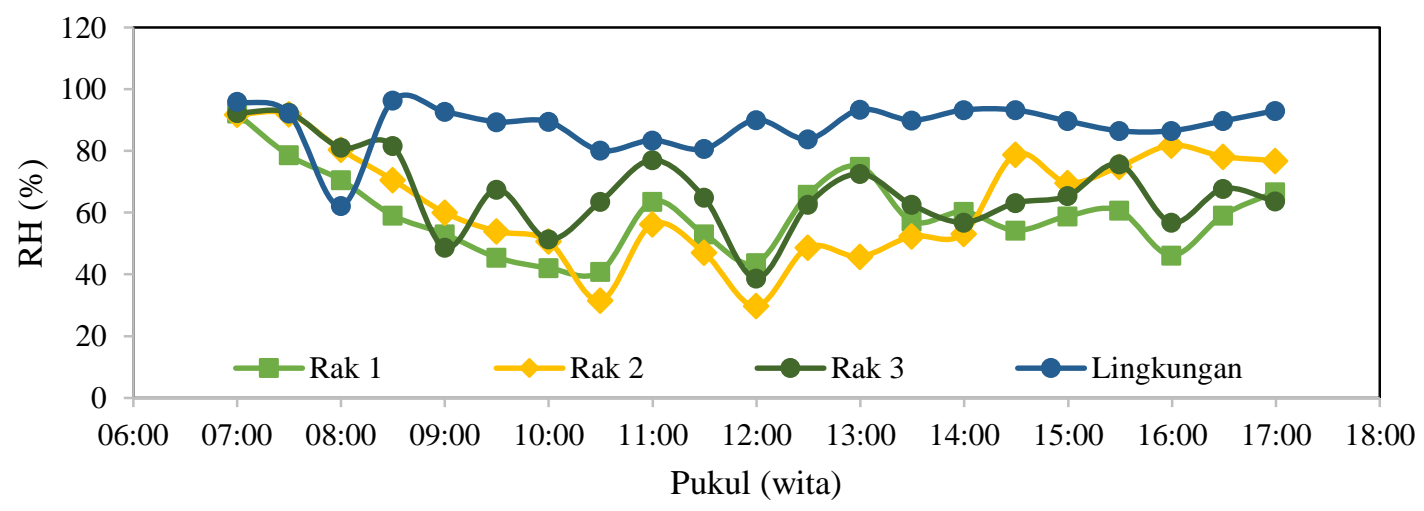

Gambar 5. Grafik RH Tiap Rak dengan Lingkungan pada Kondisi Tanpa Bahan 


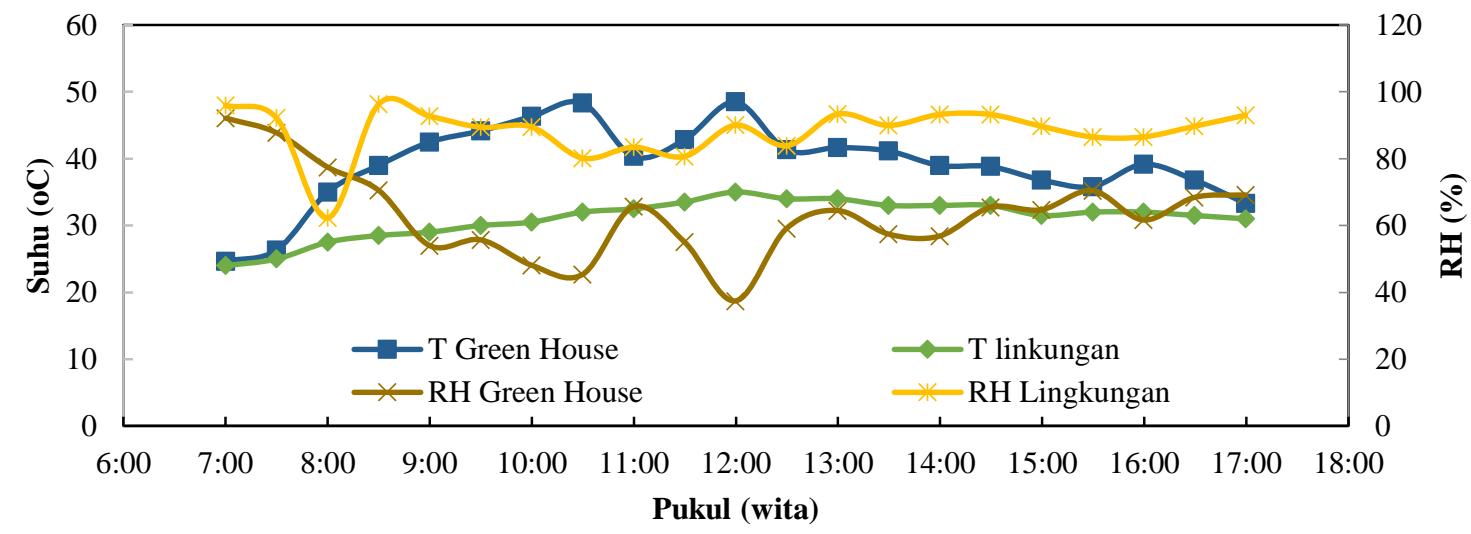

Gambar 6. Perbandingan Suhu dan RH di dalam Greenhouse dengan di Luar

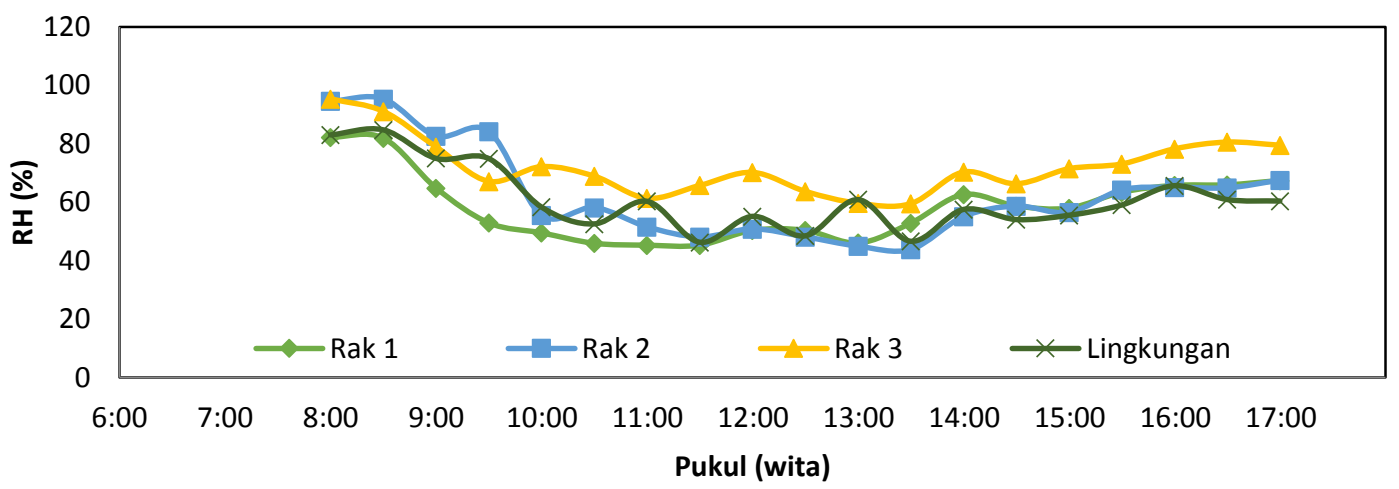

Gambar 7. Grafik RH pengeringan sawut mocaf pada hari pertama

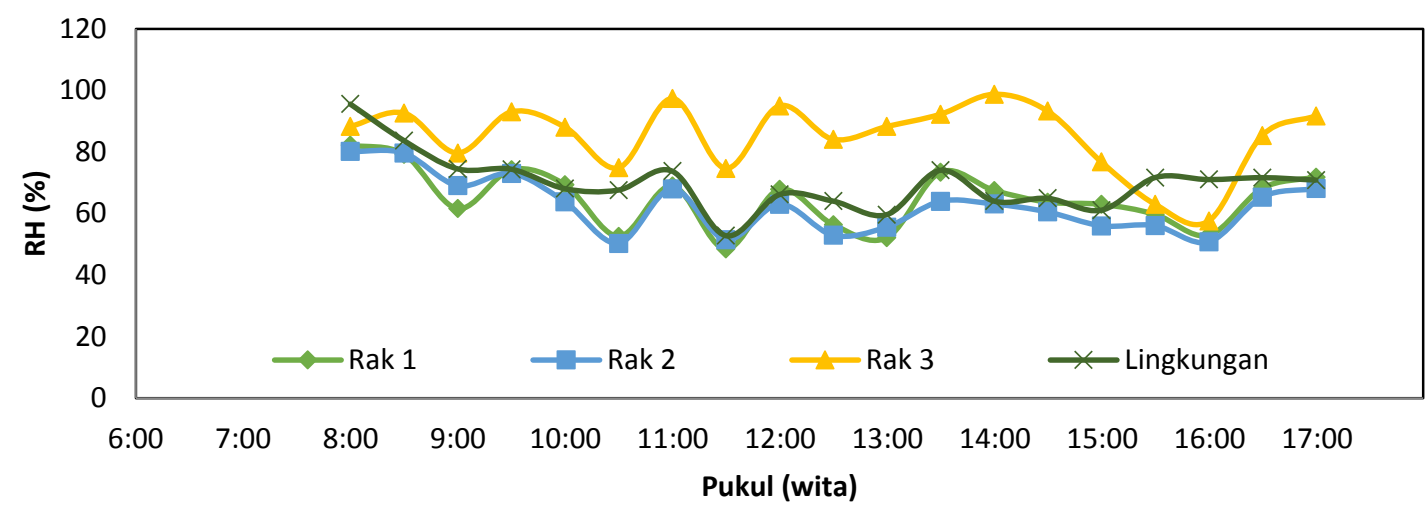

Gambar 8. Grafik RH pengeringan sawut mocaf pada hari kedua

\section{Berat Bahan (gram)}

Berdasarkan Grafik pada Gambar 10. menunjukkan bahwa, berat bahan terus menurun seiring dengan lamanya waktu pengeringan yang dilakukan. Semakin lama waktu pengeringan, kandungan air dalam bahan akan semakin cepat menguap dan bahan akan cepat kering sehingga berat bahannya juga berkurang. Penurunan berat berpotensi untuk terjadinya kondensasi atau embun di dalam ruang pengering, karena suhu dan RH lingkungan pada malam hari relatif lebih rendah dari pada suhu dan $\mathrm{RH}$ di dalam ruang pengering, akan tetapi hal tersebut dapat dihindari dengan mengaplikasikan kipas (exhaust fan) sehingga kondisi udara di dalam rauang pengering tetap rendah. 


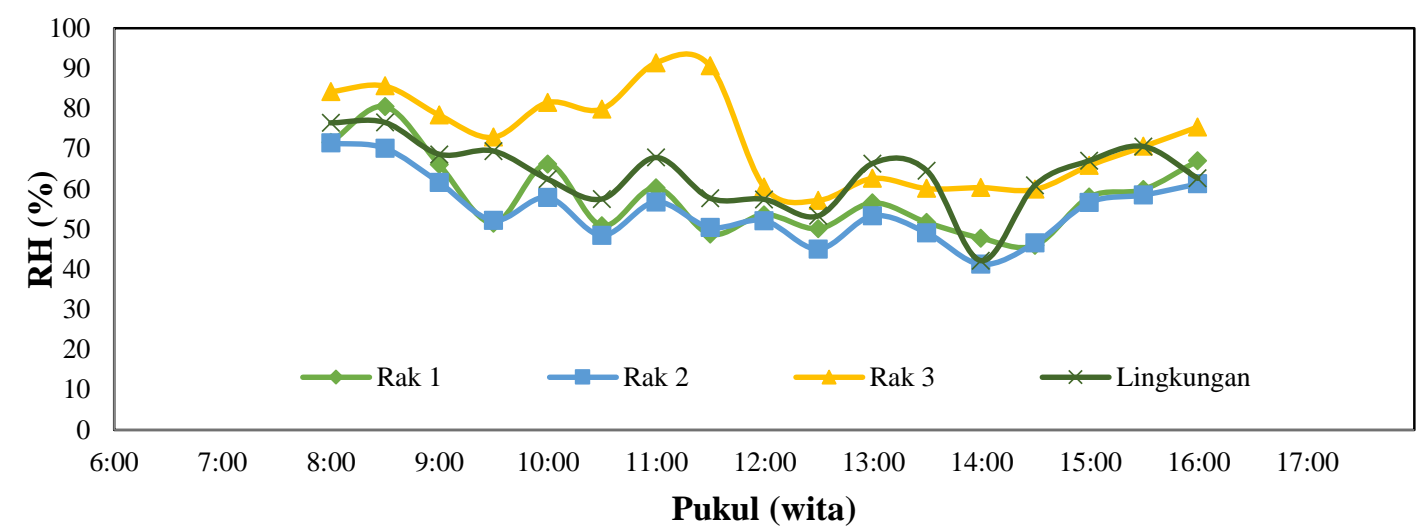

Gambar 9. Grafik RH pengeringan sawut mocaf pada hari ketiga

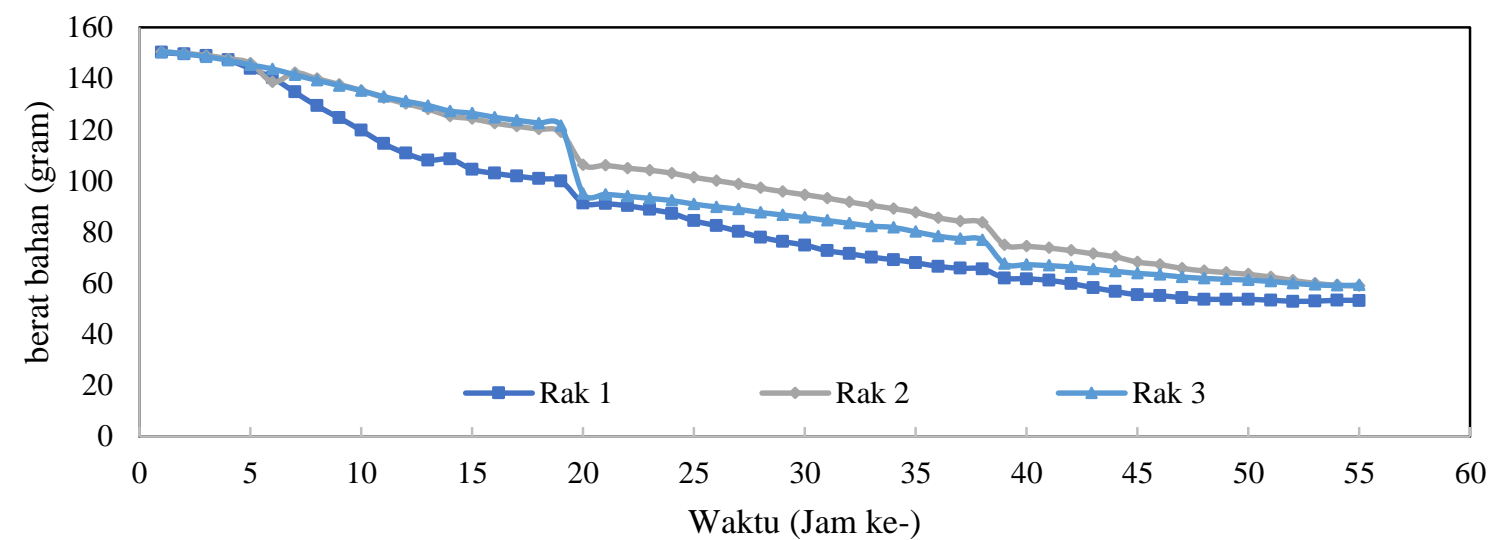

Gambar 10. Grafik Perubahan berat bahan (gram) selama pengeringan sawut mocaf (jam)

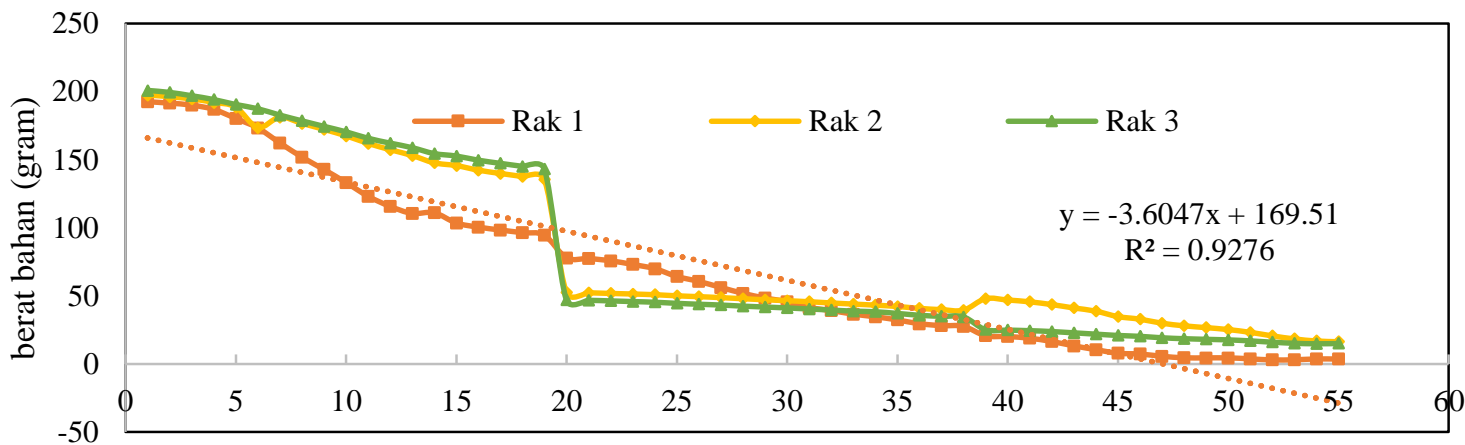

Waktu (Jam ke-)

Gambar 11. Grafik penurunan kadar air sawut Mocaf selama tiga hari

\section{Kadar Air (\%)}

Kadar air awal sawut mocaf pada pengeringan ini berkisar antara 65-67 \%, dimana perlakuan pada pengeringan ini sama dengan perlakuan pada pengeringan lapis tipis sehingga kadar air yang dimiliki tinggi. Berdasarkan Grafik pada Gambar 11. menunjukkan bahwa kadar air terus menurun seiring dengan lamanya waktu pengeringan yang dilakukan. Semakin lama waktu pengeringan, proses pelepasan air pada bahan semakin tinggi. Murad, dkk, (2015) menyatakan bahwa tingginya suhu pada ruang pengering menyebabkan penurunan massa yang lebih sedikit, sehingga lapisan terluar pada bahan kering terlebih dahulu dan menyebabkan pori-pori bahan menjadi lebih rapat sehingga kadar air yang terdapat di 
dalam bahan sulit teruapkan. Dengan demikian suhu yang terlalu tinggi juga kurang baik digunakan untuk pengeringan.

\section{Kadar Air Keseimbangan (\%)}

Dari hasil penelitian terlihat bahwa dengan kadar air keseimbangan akan semakin menurun apabila suhu ruang pengering semakin meningkat. Hal ini disebabkan karena pada ruang pengering dengan kondisi suhu yang tinggi akan memiliki kelembaban relatif yang rendah sehingga laju penguapan akan semakin banyak dan lebih cepat. Dengan kata lain dapat disimpulkan bahwa kadar air keseimbangan tergantung dari suhu lingkungan bahan tersebut serta $\mathrm{RH}$ udara. Kadar air kesetimbangan didefinisikan sebagai kadar air dimana tekanan uap internal bahan dalam kondisi keseimbangan dengan tekanan uap lingkungan. konsep kadar air keseimbangan penting di dalam pengeringan karena kadar air keseimbangan menentukan kadar air minimum dimana bahan dapat dikeringkan pada kondisi pengeringan tertentu. Untuk mencapai kadar air keseimbangan dengan ruang udara pengering, maka bahan harus mengeluarkan air lebih banyak (Murad, dkk, 2015).

Sabani, R., dkk., 2013, menyatakan bahwa bahan yang bersifat higroskopis akan mengalami pelepasan air (desorbsi) maupun

penyerapan air (absorbsi) untuk mencapai keseimbangan dengan lingkungannya. Pada akhir pengeringan tekanan uap bahan pangan seimbang dengan tekanan uap parsial dari udara pengering, sehingga tidak terjadi lagi proses pengeringan pada kondisi kadar air keseimbangan. Suatu bahan dalam keadaan seimbang apabila laju kehilangan air dari bahan ke udara sekeliling sama dengan laju penambahan air ke bahan dari udara sekelilingnya. Kadar air dalam keadaan seimbang ini dinamakan kadar air higroskopis (Henderson dan Perry, 1976). Variasi kadar air keseimbangan mocaf untuk berbagai tingkatan suhu dan kelembaban pada penelitian tahap pertama disajikan pada Tabel 1.

Tabel 1. Variasi Kadar Air Keseimbangan Sawut Mocaf pada Berbagai Tingkatan Suhu dan RH

\begin{tabular}{ccc}
\hline $\begin{array}{c}\text { Suhu } \\
\text { Ruang } \\
\begin{array}{c}\text { Pengering } \\
\left({ }^{\circ} \mathrm{C}\right)\end{array}\end{array}$ & $\begin{array}{c}\text { Kelembaban } \\
\text { Relatif }(\%)\end{array}$ & $\begin{array}{c}\text { Kadar Air } \\
\text { Keseimbangan } \\
(\% \mathrm{db})\end{array}$ \\
\hline 40 & 66,54 & 16,80 \\
50 & 65,46 & 15,93 \\
60 & 50,70 & 14,31 \\
70 & 49,85 & 12,38 \\
80 & 48,00 & 11,69 \\
\hline
\end{tabular}

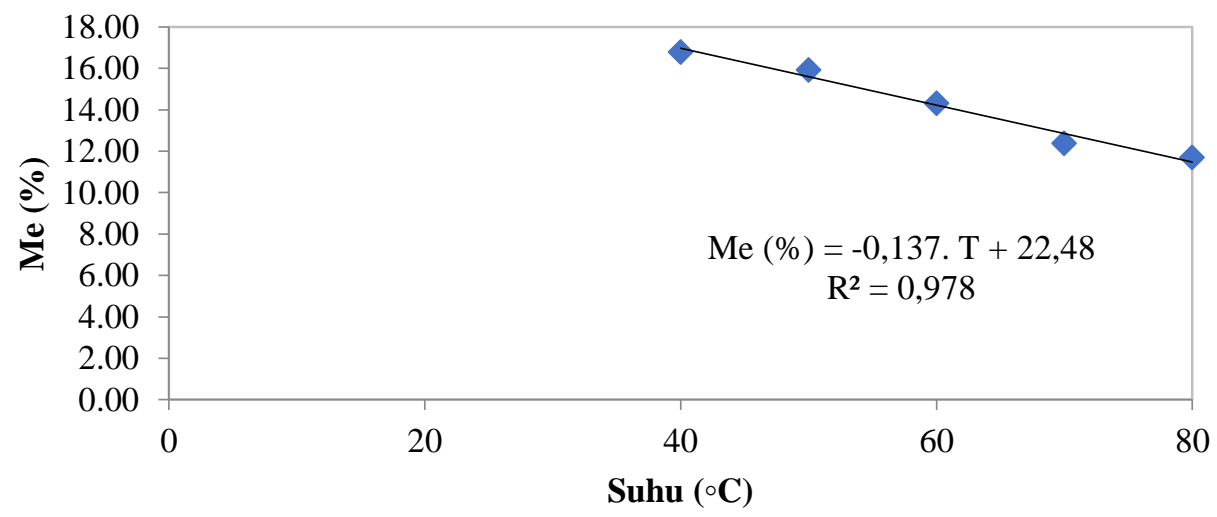

Gambar 12. Grafik Hubungan Suhu Ruang Pengering $\left({ }^{\circ} \mathrm{C}\right)$ Terhadap Me (\% db) Sawut Mocaf Selama Proses Pengeringan untuk Lima Level Suhu Pengeringan

Dari tabel 1 dapat dilihat bahwa nilai kelembaban relatif dan kadar air keseimbangan semakin menurun dengan semakin meningkatnya suhu ruang pengering. Ini dikarenakan telah terjadi pelepasan air yang banyak dan cepat pada 
suhu ruang pengering yang tinggi. Sehingga dapat disimpulkan bahwa bahan akan cepat mengering pada kondisi suhu ruang pengering yang tinggi. Pelepasan air dari dalam mocaf akan semakin menurun dengan semakin rendahnya suhu ruang pengering dan kelembaban relatif. Pernyataan dari hal tersebut dapat dilihat grafik pada gambar 12 berikut ini.

Berdasarkan grafik pada gambar 12 menunjukkan bahwa kadar air keseimbangan dipengaruhi oleh suhu ruang pengering, hal ini dapat dilihat semakin tinggi suhu ruang pengering, maka akan semakin rendah kadar air keseimbangan. Ini sesuai dengan pernyataan Murad, dkk (2015), bahwa semakin tinggi suhu ruang pengering, maka akan semakin rendah kadar air keseimbangan. Nilai determinasi yang diperoleh mendekati angka 1 yaitu $\mathrm{R}^{2}=0,978$ maka dapat disimpulkan bahwa data sangat cocok untuk pengeringan komoditas sawut mocaf.

\section{Laju Pengeringan}

Secara umum proses pengeringan terbagi dalam dua periode meliputi periode laju pengeringan tetap dan periode laju pengeringan menurun (Henderson dan Perry, 1976). Laju penguapan air adalah banyaknya air yang diuapkan setiap satuan waktu atau penurunan kadar air bahan dalam satuan waktu dan laju pengeringan bervariasi sesuai dengan jenis bahan yang dikeringkan dan jenis proses pengeringan yang digunakan (Murad, dkk., 2015). Pada pengeringan lapis tipis, dilakukan pengambilan data setiap 30 menit dengan satuan massa gram sampai dengan kadar air keseimbangan. Adapun hasil laju pengeringan yang didapatkan ditunjukkan pada gambar 13.

Berdasarkan grafik pada gambar 13 menunjukkan bahwa laju pengeringan sawut mocaf tidak teratur. Terdapat beberapa titik terjadinya kenaikan laju pengeringan. Hal tersebut dimungkinkan karena adanya perbedaan penurunan berat bahan per satuan waktu yang digunakan, namun dengan demikian berat bahan tetap menurun. Berdasarkan hasil laju pengeringan tersebut, dapat dikatakan bahwa sawut mocaf memiliki laju pengeringan konstan yang terjadi dari jam ke 1 sampai dengan jam ke 12 dan seiring dengan berkurangnya kadar air dalam bahan laju pengeringan menjadi menurun dari jam ke 12 sampai dengan jam ke 37. Laju pengeringan menurun merupakan titik dimana sudah tidak terdapat penguapan air dalam bahan sehingga tidak menyebabkan berat bahan menurun kembali.

\section{KESIMPULAN}

1. Proses pengeringan Sawut Mocaf dengan menggunakan alat pengering tipa green house atau ERK dapat dilakukan dari kadar air awal bahan $67 \%$ menjadi $10 \%$ dalam waktu kurang lebih 3 hari.

2. Semakin tinggi suhu pada ruang pengering maka semakin banyak terjadi penurunan kadar air per satuan waktu.

3. Penggunaan exhaust fan pada malam hari dapat mempertahankan kondisi $\mathrm{RH}$ ruangan green house meski tanpa alat pemanas buatan.

4. Karakteristik pengeringan sawut mocaf pada alat pengering tenaga surya tipe greenhouse tentang hubungan $\ln$ MR (\% $\mathrm{db}$ ) dengan waktu $\mathrm{t}$ (jam) menunjukkan bahwa semakin tinggi suhu pada ruang pengering maka semakin banyak penurunan kadar air per satuan waktu, sehingga laju pengeringan bersifat menurun.

5. Terdapat beberapa titik laju kosntan mulai dari jam ke 1 sampai dengan jam ke 12 dan terjadi laju pengeringan penurunan sawut mocaf pada alat pengering tenaga surya tipe greenhouse mulai dari jam ke 12 sampai dengan jam ke 37, hal tersebut terjadi karena adanya perbedaan penurunan berat bahan dan dipengaruhi juga oleh waktu pengeringan seiring dengan intensitas matahari serta kenaikan suhu ruang pengering.

\section{DAFTAR REFERENSI}

Hidayat, B., Kalsum, N., dan Surfiana. (2009). Karakterisasi Tepung Ubi Kayu Modifikasi yang Diproses 


$\begin{array}{lr}\text { Menggunakan } & \text { Metode } \\ \text { Pragelatinisasi Parsial. } & \text { Jurnal } \\ \text { Teknologi Industri dan Hasil } \\ \text { Pertanian Volume 14, No 2, } \\ \text { September 2009. }\end{array}$

BPS. (2016). Nusa Tenggara Barat dalam Angka 2015. Kerjasama Badan Perencanaan Pembangunan Daerah (BAPPEDA) Propinsi Nusa Tenggara Barat dengan Badan Pusat Statistik Provinsi Nusa Tenggara Barat.

Henderson, S.M., and Perry, R.L. (1976). Agricultural Proses Engineering. 3rd ed. The AVI Publ. co., Inc, Wesport, Connecticurt USA

Murad, Rahmat, S., Kurniawan, H., Khalil, F.I, dan Muttalib, S.A. (2017). Pengeringan Sawut Singkong Fermentasi (MOCAF) pada Alat Pengering Tenaga Surya Tipe Greenhouse. Laporan Penelitian Hibah Bersaing. LPPM Universitas Mataram. Mataram

Murad, Sabani, R., Putra, G.M.D. (2015). Pengeringan Kopra Putih pada Alat
Pengering Tipe Rak (Tray Dryer) Menggunakan Energi Surya. Laporan Penelitian Hibah Bersaing. LPPM Universitas Mataram. Mataram.

Murad, Sukmawaty, Sabani, R., dan Putra, G.M.D. (2015). Pengeringan Biji Kemiri pada Alat Pengering Tipe Batch Model Tungku Berbasis Bahan Bakar Cangkang Kemiri. Jurnal Ilmiah Rekayasa Pertanian dan Biosistem, 3 (1), Maret 2015.

Sabani, R., Murad, Abdullah,S.H., dan Priyati, A. (2013). Pengeringan Biji Kakao pada Alat Pengering Hybrid Tipe Rak. Fakultas Teknologi Pangan dan Agroindustri Universitas Mataram. Mataram.

Wulandani, D., dan Utari, S. (2013). Analisis Pengeringan Sawut Ubi Jalar (Ipomoea batatas L.) Menggunakan Pengering Efek Rumah Kaca (ERK). Jurnal Teknik Pertanian, 1 (1), Oktober 2013. Institut Pertanian Bogor. Bogor. 